\title{
UJI SENSITIVITAS METODE $A R A S$ DENGAN PENDEKATAN METODE PEMBOBOTAN KRITERIA SAHNNON ENTROPY DAN SWARA PADA PENYELEKSIAN CALON KARYAWAN
}

\author{
Halimah, Dwi Kartini, Friska Abadi, Irwan Budiman, Muliadi \\ Program Studi Ilmu Komputer, Fakultas MIPA, Universitas Lambung Mangkurat, Banjarmasin, Indonesia \\ e-mail: j1f115029@mhs.ulm.ac.id, \{dwikartini, friska.abadi, irwan.budiman, muliadi\}@ulm.ac.id
}

Diterima: 1 Mei 2020 - Direvisi: 12 Juni 2020 - Disetujui: 15 Juni 2020

\begin{abstract}
This study conducts the sensitivity test of the Additive Ratio Assessment (ARAS) method for selecting prospective employees using the criteria weighting approach using the Shannon Entropy method and the Stepwise Weight Assessment Ratio Analysis (SWARA) method which aims to measure how sensitive this method is when applied to a decision-making case. The data used is the prospective employee selection data. The Sentitivity Test in this study is used to find out which methods are more sensitive when applied to a case. The ranking method uses ARAS because this ranking method has a utility function and an optimization value. The Shannon Entropy method uses criteria weights based on the calculation of alternative data for employee selection, while the SWARA method gives criteria weights from experts or decision makers. The results of this study indicate that the most sensitive method for the selection of prospective employees is the SWARA-ARAS method, which gives weight based on experts or decision makers with a result of $91.24203 \%$ higher than the Shannon Entropy-ARAS method which yields $74.75263 \%$.
\end{abstract}

Keywords: ARAS, Sensitivity Test, Shannon Entropy, SWARA.

\begin{abstract}
ABSTRAK
Penelitian ini melakukan uji sensitivitas metode Additive Ratio Assessment (ARAS) pada penyeleksian calon karyawan dengan pendekatan pembobotan kriteria menggunakan metode Shannon Entropy dan metode Stepwise Weight Assessment Ratio Analysis (SWARA) yang bertujuan untuk mengukur seberapa sensitif metode ini jika diterapkan pada sebuah kasus pengambilan keputusan. Data yang digunakan ialah data penyeleksian calon karyawan. Uji Sentitivitas pada penelitian ini digunakan untuk mengetahui metode yang lebih sensitif saat diterapkan pada suatu kasus. Metode perangkingan menggunakan ARAS karena metode perangkingan ini memiliki fungsi utilitas dan nilai optimalisasi. Metode Shannon Entropy bobot kriteria diperoleh berdasarkan perhitungan data alternatif penyeleksian karyawan, sedangkan metode SWARA bobot kriteria diperoleh dari pakar atau si pengambil keputusan. Hasil penelitian ini menunjukkan bahwa metode yang paling sensitif dengan kasus penyeleksian calon karyawan adalah metode SWARA-ARAS yang pemberian bobotnya berdasarkan pakar atau si pengambil keputusan dengan hasil sebesar 91,24203\% lebih tinggi dibandingkan metode Shannon Entropy-ARAS yang hasil sebesar 74,75263\%.
\end{abstract}

Kata Kunci: ARAS, Shannon Entropy, SWARA, Uji Sensitivitas.

\section{Pendahuluan}

$\mathrm{P}$ ERUSAHAAN merupakan suatu kumpulan atau organisasi yang menghasilkan dan menawarkan barang, jasa kepada konsumen. Di setiap perusahaan tentu memiliki karyawan, dalam memperoleh karyawan tersebut perusahaan perlu melakukan penyeleksian calon karyawan dengan menilai beberapa aspek seperti Tes Kemampuan Dasar (TKD), Tes Intelegensi Umum (TIU), Wonderlic Personnel Test (WPT), Dominant, Influencing, Steadiness, Conscientiousness (DISC), KREAPELIN, Tes Observasi dan Wawancara. Sistem Pendukung Keputusan (SPK) atau Decision Support System adalah sistem yang bertujuan untuk menyediakan informasi, membimbing, memberikan prediksi, serta mengarahkan pengguna informasi agar dapat melakukan pengambilan keputusan dengan 


\section{Jurnal ELTIKOM : Jurnal Teknik Elektro, Teknologi Informasi dan Komputer}

lebih baik dan berbasis fakta (evidence) [1]. Arsitektur SPK terdiri dari beberapa subsistem seperti subsistem manajemen data, subsistem manajemen model, subsistem antarmuka pengguna, dan subsistem manajemen berbasis pengetahuan [2].

Uji sensitivitas pada metode $S S, S A W, W P$ dan TOPSIS pada kasus seleksi penerima beasiswa di $A n$ Australian university department, menyatakan bahwa metode TOPSIS adalah metode yang paling sensitif dan metode $W P$ adalah metode yang paling tidak sensitif dengan masing-masing persentase perubahan seperti berikut yaitu TOPSIS 53.0\%, SS 43.4\%, SAW 43.1\%, dan WP 35.2\%. Sehingga metode TOPSIS adalah metode yang paling relevan digunakan untuk kasus tersebut [3]. Pada uji sensitivitas juga terdapat dua cara dalam melakukan perubahan kriteria yaitu dengan absolute term dan relative term [4].

Salah satu metode perangkingan yaitu metode Additive Ratio Assessment (ARAS) yang diterapkan kedalam sebuah studi kasus nyata dari evaluasi iklim mikro di ruang kantor. Studi kasus ini bertujuan untuk menentukan iklim di dalam lokasi, di mana orang bekerja, dan menentukan tindakan yang harus diambil untuk memperbaiki lingkungan mereka [5]. ARAS digunakan untuk menentukan pemilihan trainer berdasarkan kriteria pada data calon trainer atau tenaga pengajar yang dibutuhkan oleh Lembaga Pendidikan [6]. Metode ARAS digunakan untuk manajemen data para calon karyawan dan beberapa kriteria yang terkomputerisasi mulai dari penyesuaian alternatif, hitung pembobotan, perhitungan nilai dominasi, hitung preferensi, dan perhitungan nilai indeks [7].

Metode Shannon Entropy merupakan metode yang dapat memberikan bobot terhadap suatu data yang dipertimbangkan dalam teori probabilitas. Metode ini juga tergantung pada penilaian objektif yang menekankan pentingnya penilaian subjektif dan spesifikasi kriteria pada tingkat bobot kriteria yang dapat diberikan bersama-sama dengan bobot entropy [8]. Shannon's Entropy dan Multiple Attribute Decision Making (MADM) digunakan untuk perluasan metode Shannon Entropy pada data yang kurang tepat, terutama pada kasus data interval dan fuzzy yang akan memperoleh atau menghasilkan bobot interval setiap kriteria [9]. Shannon Entropy berfungsi untuk menentukan bobot kriteria data dan Fuzzy TOPSIS sebagai penentuan peringkat pemasok dalam pemilihan pemasok pada risiko rantai pasokan [10]. Fuzzy Shannon Entropy untuk menghitung relatif kepentingan dan Fuzzy COPRAS untuk menentukan peringkat berdasarkan kinerja Customer Relationship Management (CRM) melalui data evaluasi kinerja $C R M[11]$.

Metode pembobotan yang melakukan pemberian nilai atau bobot menggunakan Stepwise Weight Assessment Ratio Analysis (SWARA) untuk memperluas pengetahuan tentang metode SWARA dalam meningkatkan kualitas dari proses penentuan keputusan dengan memasukkan keandalan gagasan dari para ahli sebagai langkah pertama [12]. Perbandingan antara metode SWARA dan AHP bertujuan untuk menyeleksi kemasan yang baik dan yang paling diinginkan oleh pelanggan dari produk anggur [13]. Pengambilan keputusan dan kebijakan industri teknologi tinggi di Iran dengan menggunakan metode SWARA untuk mengevaluasi dan menimbang kriteria, serta COPRAS untuk menentukan peringkat alternatif yang melibatkan 11 orang para ahli untuk mendapatkan keputusan [14]. Metode SWARA dan metode ARAS digunakan untuk membangun model Multi Criteria Decision Making (MCDM) dalam mengevaluasi dan menseleksi calon karyawan pada proses perekrutan dan pemilihan personil [15].

Proses penyeleksian calon karyawan selama ini masih dilakukan dengan membandingkan nilai kriteria setiap alternatif, hal ini dikarenakan belum adanya bobot yang jelas untuk setiap kriteria penilaian. Kriteria penilaian penyeleksian calon karyawan terdiri dari Tes Kemampuan Dasar (TKD), Tes Intelegensi Umum (TIU), Wonderlic Personnel Test (WPT), Dominant, Influencing, Steadiness, Conscientiousness (DISC), KREAPELIN, Tes Observasi dan Wawancara. Dua metode pembobotan yang akan digunakan memiliki perbedaan yaitu metode Shannon Entropy penentuan bobot awalnya diperoleh dari nilai data alternatif calon karyawan yang terdaftar dan metode SWARA penentuan bobot awalnya diperoleh melalui wawancara dengan pakar atau si pengambil keputusan. Sedangkan metode perangkingan yang digunakan ialah $A R A S$ yang memiliki nilai fungsi utilitas dan nilai optimalisasi. Oleh karena itu, peneliti akan melakukan perbandingan uji sensitivitas metode perangkingan ARAS pada kasus penyeleksian calon karyawan dengan pendekatan metode pembobotan Shannon Entopy dan SWARA. 


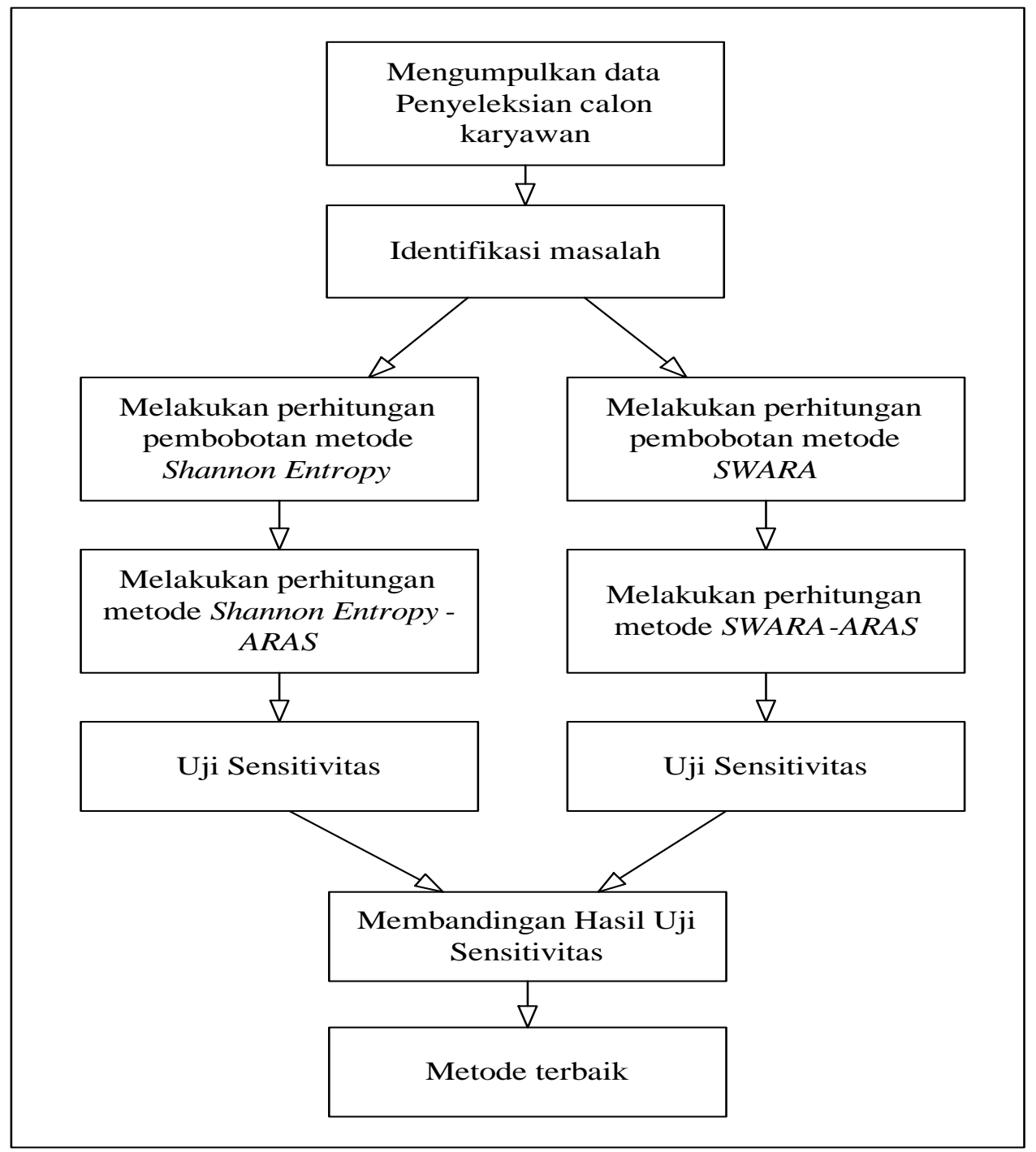

Gambar. 1. Flowchart Penelitian Uji Sensitivitas Metode Shannon Entropy-ARAS dan SWARA-ARAS

\section{Metode Penelitian}

Data yang dikumpulkan melalui wawancara langsung dengan Human Resources (HR) berupa data penyeleksian calon karyawan yang terdiri dari beberapa aspek penilaian seperti Tes Kemampuan Dasar (TKD), Tes Intelegensi Umum (TIU), Wonderlic Personnel Test (WPT), Dominant, Influencing, Steadiness, Conscientiousness (DISC), KREAPELIN, Tes Observasi dan Wawancara. Data tersebut juga memuat hasil akhir penilaian dari setiap calon karyawan yang terdiri dari 56 orang. Penentuan calon karyawan yang layak diterima ditentukan dari kalkulasi semua aspek penilaian, akan tetapi $H R$ akan membandingkan nilai setiap kriteria secara manual dengan memperhatikan beberapa aspek tersebut sesuai kepentingan.

Dari proses pengumpulan data tadi peneliti mengidentifikasikan bahwa belum ada pembobotan pada aspek penilaian penyeleksian calon karyawan. Oleh karena itu, peneliti melakukan pembobotan dengan menggunakan metode Shannon Entropy yang proses pembobotannya ditentukan dari data penyeleksian calon karyawan dan metode Stepwise Weight Assessment Ratio Analysis (SWARA) pembobotannya diperoleh dari wawancara dengan $H R$. Perhitungan pembobotan metode Shannon Entropy pertama kali diusulkan oleh Shannon pada tahun 1948 dan dikembangkan lagi oleh Wang dan Lee pada tahun 2009 dengan memberikan bobot terhadap suatu data menggunakan teori probalitas [8].

Pembobotan metode Stepwise Weight Assessment Ratio Analysis (SWARA) merupakan metode yang berorientasi berdasarkan sudut pandang ahli atau pengambil keputusan yang berperan penting dalam menentukan prioritas metode pembobotan [16]. Hasil pembobotan yang diperoleh dari metode Shannon 


\section{Jurnal ELTIKOM : Jurnal Teknik Elektro, Teknologi Informasi dan Komputer}

TABEL 1

KRITERIA PENILAIAN CALON KARYAWAN

\begin{tabular}{cl} 
& \multicolumn{1}{c}{ KRITERIA PENILAIAN CALON KARYAWAN } \\
\hline \hline Kode & \multicolumn{1}{c}{ KETERANGAN } \\
\hline TKD & Tes Kemampuan Dasar \\
TIU & Tes Intelegensi Umum \\
WPT & Wonderlic Personnel Test \\
DISC & Dominant, Influencing, Steadiness, Conscientiousness \\
KP & KREAPELIN \\
TO \& W & Tes Observasi dan Wawancara \\
\hline \hline
\end{tabular}

TABEL 2

DATA CALON KARYAWAN

\begin{tabular}{cccccccc}
\hline \hline No & KODE & TKD & TIU & WPT & DISC & KP & TO \& W \\
\hline 1 & CKX1 & 6 & 14 & 11 & 9 & 153 & 74 \\
2 & CKX2 & 7 & 16 & 14 & 9 & 182 & 84 \\
3 & CKX3 & 12 & 28 & 13 & 8 & 187 & 88 \\
4 & CKX4 & 6 & 15 & 6 & 9 & 170 & 79 \\
5 & CKX5 & 8 & 20 & 9 & 10 & 31 & 74 \\
6 & CKX6 & 11 & 13 & 9 & 11 & 216 & 74 \\
7 & CKX7 & 10 & 24 & 11 & 10 & 210 & 70 \\
8 & CKX8 & 9 & 11 & 9 & 9 & 186 & 78 \\
9 & CKX9 & 10 & 20 & 13 & 8 & 327 & 79 \\
10 & CKX10 & 5 & 20 & 9 & 9 & 60 & 75 \\
$\ldots$ & $\ldots$ & $\ldots$ & $\ldots$ & $\ldots$ & $\ldots$ & $\ldots$ & $\ldots$ \\
56 & CKX56 & 13 & 24 & 16 & 9 & 221 & 88 \\
\hline
\end{tabular}

Entropy dan SWARA, akan dilakukan proses perangkingan alternatif menggunakan metode Additive Ratio Assessment (ARAS). Hasil perangkingan metode Shannon Entropy-ARAS dan metode SWARA$A R A S$ digunakan sebagai nilai peringkat awal pada tahapan uji sensitivitas. Persentase perubahan peringkat uji sensitivitas pada setiap metode tersebut dilakukan perbandingan untuk mengetahui metode yang lebih sensitif berdasarkan angka persentase yang paling tinggi. Adapun flowchart penelitian dapat dilihat pada Gambar 1.

\section{HASIL DAN PEMBAHASAN}

\section{A. Hasil}

Proses pengumpulan data didapatkan dari hasil wawancara dan observasi dengan Human Resources $(H R)$. Data yang digunakan untuk penelitian ini sebanyak 56 orang calon karyawan dan terdiri dari enam kriteria seperti Tes Kemampuan Dasar dengan kode TKD, Tes Intelegensi Umum dengan kode TIU, Wonderlic Personnel Test dengan kode WPT, Dominant, Influencing, Steadiness, Conscientiousness dengan kode DISC, KREAPELIN dengan kode KP, Tes Observasi dan Wawancara dengan kode TO\&W. Kiteria-kriteria penilaian dapat dilihat pada Tabel I dan data calon karyawan dapat dilihat pada Tabel II. Setelah mendapatkan data-data yang diperlukan peneliti akan melakukan perhitungan pembobotan menggunakan metode Shannon Entropy dan metode SWARA, serta melakukan perangkingan alternatif metode $A R A S$ dan Uji Sensitivitas.

\section{1) Shannon Entropy}

Hasil perhitungan nilai bobot setiap kriteria metode Shannon Entropy dapat dilihat pada Tabel 3.

\section{2) SWARA}

Nilai bobot kriteria yang didapat dari si pengambil keputusan yaitu TKD 90\%, TIU 70\%, WPT 60\%, DISC 80\%, KP 50\%, dan TO\&W 100\%, maka nilai setiap kriteria tersebut akan di proses pada metode SWARA. Hasil perhitungan nilai bobot setiap kriteria metode SWARA dapat dilihat pada Tabel 4.

\section{3) Shannon Entropy-ARAS}

Hasil peringkat alternatif yang didapatkan dari perangkingan metode $A R A S$ dengan menggunakan bobot metode Shannon Entropy dapat dilihat pada Tabel 5, dengan nilai maks atau alternatif terbesar yaitu 0.47442 yang nantinya akan digunakan pada tahapan uji sensitivitas.

\section{4) SWARA-ARAS}

Hasil peringkat alternatif yang didapatkan dari perangkingan metode $A R A S$ dengan menggunakan bobot metode SWARA dapat dilihat pada Tabel 6, dengan nilai maks atau alternatif terbesar yaitu 
TABEL 3

BOBOT SETIAP KRITERIA SHANNON ENTROPY

\begin{tabular}{|c|c|c|c|c|c|c|c|}
\hline \multirow{2}{*}{ W } & TKD & TIU & WPT & DISC & $\mathrm{KP}$ & TO \& W & TOTAL \\
\hline & 0,20186 & 0,16485 & 0,21877 & 0,05427 & 0,35104 & 0,00921 & 1 \\
\hline \multicolumn{8}{|c|}{ TABEL 4} \\
\hline \multirow{2}{*}{ W } & TO \& W & TKD & DISC & TIU & WPT & KP & 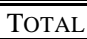 \\
\hline & 0,46086 & 0,24256 & 0,13475 & 0,07927 & 0,04954 & 0,03303 & 1 \\
\hline
\end{tabular}

TABEL 5

HASIL PERINGKAT ALTERNATIF SHANNON ENTROPY-ARAS

\begin{tabular}{|c|c|c|c|c|c|c|c|c|c|}
\hline \multirow{2}{*}{ No } & \multirow{2}{*}{ KODE } & MAX & MAX & MAX & MIN & MAX & MAX & \multirow{2}{*}{$\begin{array}{c}\text { NILAI } \\
\text { OPTIMALISASI }\end{array}$} & \multirow{2}{*}{$\begin{array}{l}\text { PERINGKAT } \\
\text { ALTERNATIF }\end{array}$} \\
\hline & & TKD & TIU & WPT & DISC & $\mathrm{KP}$ & TO \& W & & \\
\hline 1 & $\mathrm{X} 0$ & 0,00903 & 0,0054 & 0,02048 & 0,0082 & 0,01726 & 0,000210 & 0,06059 & 1 \\
\hline 2 & CKX1 & 0,00271 & 0,00252 & 0,00451 & 0,00091 & 0,0066 & 0,000155 & 0,01741 & 0,28728 \\
\hline 3 & CKX2 & 0,00316 & 0,00288 & 0,00574 & 0,00091 & 0,00785 & 0,000176 & 0,02072 & 0,34197 \\
\hline 4 & CKX3 & 0,00542 & 0,00504 & 0,00533 & 0,00103 & 0,00807 & 0,000185 & 0,02507 & 0,41373 \\
\hline 5 & CKX4 & 0,00271 & 0,0027 & 0,00246 & 0,00091 & 0,00733 & 0,000166 & 0,01628 & 0,26873 \\
\hline 6 & CKX5 & 0,00361 & 0,0036 & 0,00369 & 0,00082 & 0,00134 & 0,000155 & 0,01322 & 0,21813 \\
\hline 7 & CKX6 & 0,00497 & 0,00234 & 0,00369 & 0,00075 & 0,00932 & 0,000155 & 0,02122 & 0,35018 \\
\hline 8 & CKX7 & 0,00452 & 0,00432 & 0,00451 & 0,00082 & 0,00906 & 0,000147 & 0,02337 & 0,38578 \\
\hline 9 & CKX8 & 0,00406 & 0,00198 & 0,00369 & 0,00091 & 0,00803 & 0,000164 & 0,01883 & 0,31084 \\
\hline 10 & CKX9 & 0,00452 & 0,0036 & 0,00533 & 0,00103 & 0,01411 & 0,000166 & 0,02874 & 0,47442 \\
\hline$\ldots$ & $\ldots$ & $\ldots$ & $\ldots$ & $\ldots$ & $\ldots$ & $\ldots$ & $\ldots$ & $\ldots$ & $\ldots$ \\
\hline 57 & CKX56 & 0,00587 & 0,00432 & 0,00655 & 0,00091 & 0,00954 & 0,000185 & 0,02738 & 0,45191 \\
\hline \multicolumn{9}{|c|}{ Maks } & 0,47442 \\
\hline
\end{tabular}

TABEL 6

HASIL PERINGKAT ALTERNATIF SWARA-ARAS

\begin{tabular}{|c|c|c|c|c|c|c|c|c|c|}
\hline \multirow{2}{*}{ No } & \multirow{2}{*}{ KODE } & MAX & MAX & MIN & MAX & MAX & MAX & \multirow{2}{*}{$\begin{array}{c}\text { NILAI } \\
\text { OPTIMALISASI }\end{array}$} & \multirow{2}{*}{$\begin{array}{l}\text { PERINGKAT } \\
\text { ALTERNATIF }\end{array}$} \\
\hline & & TO \& W & TKD & DISC & TIU & WPT & KP & & \\
\hline 1 & $\mathrm{X} 0$ & 0,010512 & 0,0109 & 0,0204 & 0,0026 & 0,0046 & 0,001624 & 0,050588 & 1 \\
\hline 2 & CKX1 & 0,007779 & 0,0033 & 0,0023 & 0,0012 & 0,001 & 0,000621 & 0,016152 & 0,31928 \\
\hline 3 & CKX2 & 0,008830 & 0,0038 & 0,0023 & 0,0014 & 0,0013 & 0,000739 & 0,018315 & 0,36204 \\
\hline 4 & CKX3 & 0,009251 & 0,0065 & 0,0025 & 0,0024 & 0,0012 & 0,000759 & 0,022698 & 0,44869 \\
\hline 5 & CKX4 & 0,008305 & 0,0033 & 0,0023 & 0,0013 & 0,0006 & 0,000690 & 0,016369 & 0,32358 \\
\hline 6 & CKX5 & 0,007779 & 0,0043 & 0,002 & 0,0017 & 0,0008 & 0,000126 & 0,016850 & 0,33308 \\
\hline 7 & CKX6 & 0,007779 & 0,006 & 0,0019 & 0,0011 & 0,0008 & 0,000877 & 0,018437 & 0,36446 \\
\hline 8 & CKX7 & 0,007359 & 0,0054 & 0,002 & 0,0021 & 0,001 & 0,000852 & 0,018773 & 0,3711 \\
\hline 9 & CKX8 & 0,008200 & 0,0049 & 0,0023 & 0,001 & 0,0008 & 0,000755 & 0,017889 & 0,35362 \\
\hline 10 & CKX 9 & 0,008305 & 0,0054 & 0,0025 & 0,0017 & 0,0012 & 0,001327 & 0,020542 & 0,40607 \\
\hline$\ldots$ & $\ldots$ & $\ldots$ & $\ldots$ & $\ldots$ & $\ldots$ & $\ldots$ & $\cdots$ & $\ldots$ & $\cdots$ \\
\hline 57 & CKX56 & 0,009251 & 0,0071 & 0,0023 & 0,0021 & 0,0015 & 0,000897 & 0,023028 & 0,45521 \\
\hline & \multicolumn{8}{|c|}{ Maks } & 0,45521 \\
\hline
\end{tabular}

TABEL 7

PERINGKAT ALTERNATIF SAAT BOBOT $=1$

\begin{tabular}{cccc}
\hline \hline No. & KODE & SHANNON ENTROPY-ARAS & SWARA-ARAS \\
\hline 1 & X0 & 1 & 1 \\
2 & CKX1 & 0,28728 & 0,31928 \\
3 & CKX2 & 0,34197 & 0,36204 \\
4 & CKX3 & 0,41373 & 0,44869 \\
5 & CKX4 & 0,26873 & 0,32358 \\
6 & CKX5 & 0,21813 & 0,33308 \\
7 & CKX6 & 0,35018 & 0,36446 \\
8 & CKX7 & 0,38578 & 0,37110 \\
9 & CKX8 & 0,31084 & 0,35362 \\
10 & CKX9 & 0,47442 & 0,40607 \\
$\ldots$ & $\ldots$ & $\ldots$ & $\ldots$ \\
57 & CKX56 & 0,45191 & 0,45521 \\
\hline \multicolumn{7}{c}{ Maks } & 0,47442 & 0,45521 \\
\hline \hline
\end{tabular}

0.45521 yang nantinya akan digunakan pada tahapan uji sensitivitas.

5) Uji Sensitivitas

Hasil peringkat alternatif metode ARAS pada saat bobot $(\mathrm{w})=1$ Shannon Entropy-ARAS 0,20186, 0,16485, 0,21877, 0,05427, 0,35104, 0,00921 dan SWARA-ARAS 0,46086, 0,24256, 0,13475, 0,07927, 0,04954, 0,03303 dapat dilihat pada Tabel 7.

Perubahan bobot pada penelitian ini menggunakan uji sensitivitas relative term dengan kenaikkan 
TABEL 8

Uji SENSitivitas Pada PERUBahan BOBOt TKD + 0,3

\begin{tabular}{cccc}
\hline \hline No. & KODE & SHANNON ENTROPY-ARAS & SWARA-ARAS \\
\hline 1 & X0 & 1 & 1 \\
2 & CKX1 & 0,28959 & 0,31524 \\
3 & CKX2 & 0,34342 & 0,35952 \\
4 & CKX3 & 0,44751 & 0,48042 \\
5 & CKX4 & 0,27440 & 0,31863 \\
6 & CKX5 & 0,25111 & 0,34711 \\
7 & CKX6 & 0,38642 & 0,40337 \\
8 & CKX7 & 0,40649 & 0,39813 \\
9 & CKX8 & 0,33608 & 0,37383 \\
10 & CKX9 & 0,47906 & 0,42577 \\
$\ldots$ & $\ldots$ & $\ldots$ & $\ldots$ \\
57 & CKX56 & 0,48783 & 0,49606 \\
\hline \multicolumn{5}{c}{ Maks } & 0,48783 & 0,49606 \\
Perubahan & $2,82734 \%$ & $8,97321 \%$ \\
\hline \hline
\end{tabular}

TABEL 9

Uji Sensitivitas Pada Perubahan Bobot TIU + 0,3

\begin{tabular}{cccc}
\hline \hline No. & KODE & SHANNON ENTROPY-ARAS & SWARA-ARAS \\
\hline 1 & X0 & 1 & 1 \\
2 & CKX1 & 0,31234 & 0,34327 \\
3 & CKX2 & 0,36869 & 0,38993 \\
4 & CKX3 & 0,48630 & 0,52759 \\
5 & CKX4 & 0,30103 & 0,35230 \\
6 & CKX5 & 0,28077 & 0,38738 \\
7 & CKX6 & 0,36179 & 0,37567 \\
8 & CKX7 & 0,44363 & 0,44092 \\
9 & CKX8 & 0,31863 & 0,35574 \\
10 & CKX9 & 0,50127 & 0,44849 \\
$\ldots$ & $\ldots$ & $\ldots$ & $\ldots$ \\
57 & CKX56 & 0,50052 & 0,51134 \\
\hline \multicolumn{5}{c}{ Maks } & 0,50127 & 0,52759 \\
Perubahan & $5,65961 \%$ & $15,89937 \%$ \\
\hline \hline
\end{tabular}

TABEL 10

Uji SENSitivitas Pada Perubahan Bobot WPT+ 0,3

\begin{tabular}{cccc}
\hline \hline No. & KODE & SHANNON ENTROPY-ARAS & SWARA-ARAS \\
\hline 1 & X0 & 1 & 1 \\
2 & CKX1 & 0,26597 & 0,28383 \\
3 & CKX2 & 0,32234 & 0,33275 \\
4 & CKX3 & 0,36504 & 0,38133 \\
5 & CKX4 & 0,22162 & 0,25090 \\
6 & CKX5 & 0,20605 & 0,27843 \\
7 & CKX6 & 0,29628 & 0,29860 \\
8 & CKX7 & 0,33327 & 0,31715 \\
9 & CKX8 & 0,26939 & 0,29163 \\
10 & CKX9 & 0,40650 & 0,35392 \\
$\ldots$ & $\ldots$ & $\ldots$ & $\ldots$ \\
57 & CKX56 & 0,41012 & 0,40694 \\
\hline Maks & 0,41012 & 0,40694 \\
Perubahan & $13,55236 \%$ & $10,60467 \%$ \\
\hline \hline
\end{tabular}

sebesar 0,3 untuk masing masing kriteria. Tabel 8 adalah hasil peringkat alternatif ketika menaikkan bobot 0,3 pada kriteria TKD, sehingga menjadi Shannon Entropy-ARAS 0,50186, 0,16485, 0,21877, 0,05427, 0,35104, 0,00921 dan SWARA-ARAS 0,46086, 0,54256, 0,13475, 0,07927, 0,04954, 0,03303.

Tabel 9 adalah hasil peringkat alternatif ketika menaikkan bobot 0,3 pada kriteria TIU, sehingga menjadi Shannon Entropy-ARAS 0,20186, 0,46485, 0,21877, 0,05427, 0,35104, 0,00921 dan SWARAARAS 0,46086, 0,24256, 0,13475, 0,37927, 0,04954, 0,03303.

Tabel 10 adalah hasil peringkat alternatif ketika menaikkan bobot 0,3 pada kriteria WPT, sehingga menjadi Shannon Entropy-ARAS 0,20186, 0,16485, 0,51877, 0,05427, 0,35104, 0,00921 dan SWARAARAS 0,46086, 0,24256, 0,13475, 0,07927, 0,34954, 0,03303.

Tabel 11 adalah hasil peringkat alternatif ketika menaikkan bobot 0,3 pada kriteria DISC, sehingga menjadi Shannon Entropy-ARAS 0,20186, 0,16485, 0,21877, 0,35427, 0,35104, 0,00921 dan SWARAARAS 0,46086, 0,24256, 0,43475, 0,07927, 0,04954, 0,03303.

Tabel 12 adalah hasil peringkat alternatif ketika menaikkan bobot 0,3 pada kriteria KP, sehingga 


\section{Jurnal ELTIKOM : Jurnal Teknik Elektro, Teknologi Informasi dan Komputer}

TABEL 11

Uji SENSitivitas PADA PERUBAHAN BOBOt DISC + 0,3

\begin{tabular}{cccc}
\hline \hline No. & KODE & SHANNON ENTROPY-ARAS & SWARA-ARAS \\
\hline 1 & X0 & 1 & 1 \\
2 & CKX1 & 0,21189 & 0,22090 \\
3 & CKX2 & 0,24317 & 0,24345 \\
4 & CKX3 & 0,29016 & 0,29572 \\
5 & CKX4 & 0,20127 & 0,22317 \\
6 & CKX5 & 0,16757 & 0,22293 \\
7 & CKX6 & 0,23922 & 0,23518 \\
8 & CKX7 & 0,26347 & 0,24298 \\
9 & CKX8 & 0,22536 & 0,23901 \\
10 & CKX9 & 0,32488 & 0,27324 \\
$\ldots$ & $\ldots$ & $\ldots$ & $\ldots$ \\
57 & CKX56 & 0,30606 & 0,29259 \\
\hline \multicolumn{5}{c}{ Maks } & 0,32488 & 0,29572 \\
Perubahan & $31,52069 \%$ & $35,03712 \%$ \\
\hline \hline \multicolumn{5}{c}{}
\end{tabular}

TABEL 12

Uji Sensitivitas Pada Perubahan Bobot KP + 0,3

\begin{tabular}{cccc}
\hline \hline No. & KODE & SHANNON ENTROPY-ARAS & SWARA-ARAS \\
\hline 1 & X0 & 1 & 1 \\
2 & CKX1 & 0,30592 & 0,33355 \\
3 & CKX2 & 0,36409 & 0,38303 \\
4 & CKX3 & 0,42426 & 0,45294 \\
5 & CKX4 & 0,29932 & 0,34647 \\
6 & CKX5 & 0,19060 & 0,27538 \\
7 & CKX6 & 0,38734 & 0,40408 \\
8 & CKX7 & 0,41303 & 0,40584 \\
9 & CKX8 & 0,34102 & 0,37876 \\
10 & CKX9 & 0,54159 & 0,49895 \\
$\ldots$ & $\ldots$ & $\ldots$ & $\ldots$ \\
57 & CKX56 & 0,47160 & 0,47717 \\
\hline \multicolumn{5}{c}{ Maks } & 0,54159 & 0,49895 \\
Perubahan & $14,15740 \%$ & $9,60855 \%$ \\
\hline \hline
\end{tabular}

TABEL 13

Uji SENSitivitas PADA PERUBAHAN BOBOT TO\&W $+0,3$

\begin{tabular}{cccc}
\hline \hline No. & KODE & SHANNON ENTROPY-ARAS & SWARA-ARAS \\
\hline 1 & X0 & 1 & 1 \\
2 & CKX1 & 0,33322 & 0,36941 \\
3 & CKX2 & 0,39251 & 0,41899 \\
4 & CKX3 & 0,46105 & 0,50009 \\
5 & CKX4 & 0,32163 & 0,37915 \\
6 & CKX5 & 0,27109 & 0,38156 \\
7 & CKX6 & 0,38974 & 0,40920 \\
8 & CKX7 & 0,41767 & 0,41029 \\
9 & CKX8 & 0,35845 & 0,40442 \\
10 & CKX9 & 0,50645 & 0,45182 \\
$\ldots$ & $\ldots$ & $\ldots$ & $\ldots$ \\
57 & CKX56 & 0,49535 & 0,50583 \\
\hline \multicolumn{5}{c}{ Maks } & 0,50645 & 0,50583 \\
Perubahan & $7,03522 \%$ & $11,11910 \%$ \\
\hline \hline \multicolumn{5}{c}{}
\end{tabular}

TABEL 14

Perbandingan Persentase Perubahan Rangking Uji Sensitivitas

\begin{tabular}{cccc}
\hline \hline No. & KRITERIA & SHANNON ENTROPY-ARAS & SWARA-ARAS \\
\hline 1 & TKD $+0,3$ & $2,82734 \%$ & $8,97321 \%$ \\
2 & TIU $+0,3$ & $5,65961 \%$ & $15,89937 \%$ \\
3 & WPT $+0,3$ & $13,55236 \%$ & $10,60467 \%$ \\
4 & DISC $+0,3$ & $31,52069 \%$ & $35,03712 \%$ \\
5 & KREAPELIN $+0,3$ & $14,15740 \%$ & $9,60855 \%$ \\
6 & TO \& W $+0,3$ & $7,03522 \%$ & $11,11910 \%$ \\
\hline \multicolumn{5}{c}{ TOTAL } & $74,75263 \%$ & $91,24203 \%$ \\
\hline \hline
\end{tabular}

menjadi Shannon Entropy-ARAS 0,20186, 0,16485, 0,21877, 0,05427, 0,65104, 0,00921 dan SWARAARAS 0,46086, 0,24256, 0,13475, 0,07927, 0,04954, 0,33303.

Tabel 13 adalah hasil peringkat alternatif ketika menaikkan bobot 0,3 pada kriteria TO\&W, sehingga menjadi Shannon Entropy-ARAS 0,20186, 0,16485, 0,21877, 0,05427, 0,35104, 0,30921 dan SWARAARAS 0,76086, 0,24256, 0,13475, 0,07927, 0,04954, 0,03303. 


\section{Jurnal ELTIKOM : Jurnal Teknik Elektro, Teknologi Informasi dan Komputer}

Perbandingan jumlah persentase perubahan rangking dari Uji Sensitivitas metode Shannon EntropyARAS dan SWARA-ARAS dapat dilihat pada Tabel 14.

Dari Tabel 14, kita dapat menyatakan hasil uji sensitivitas yang didapatkan metode Shannon EntropyARAS sebesar 74,75263\% dan hasil dari metode SWARA-ARAS sebesar 91,24203\%.

\section{B. Pembahasan}

Data penyeleksian calon karyawan yang digunakan terdiri dari 56 data alternatif dengan kuota 9 alternatif yang akan diterima. Hasil pembobotan yang didapatkan dari metode Shannon Entropy ialah $\mathrm{TKD}=0,20186$, TIU $=0,16485, \mathrm{WPT}=0,21877$, DISC $=05427, \mathrm{KP}=0,35104, \mathrm{TO} \& \mathrm{~W}=0,00921$, sedangkan metode $S W A R A$ ialah TO $\& \mathrm{~W}=0,46086, \mathrm{TKD}=0,24256, \mathrm{DISC}=0,13475$, TIU $=0,07927$, $\mathrm{WPT}=0,04954, \mathrm{KP}=0,03303$. Dari masing-masing pembobotan tersebut dilakukan perangkingan menggunakan metode $A R A S$ yang menghasilkan nilai rangking dari setiap alternatif data. Untuk hasil perangkingan pada metode Shannon Entropy-ARAS terdapat 1 alternatif data yang berbeda dengan hasil data keputusan dari pihak $H R$, sedangkan hasil perangkingan pada metode SWARA-ARAS sama persis dengan hasil data keputusan dari pihak $H R$.

Uji sensitivitas dilakukan pada masing masing metode Shannon Entropy-ARAS dan SWARA-ARAS untuk mengetahui metode mana yang lebih sensitif diantara kedua kombinasi metode dengan melakukan kenaikan perubahan bobot sebesar 0,3 pada setiap kombinasi metode tersebut. Hasil metode SWARAARAS mendapatkan persentase yang lebih tinggi sebesar 91,24203\% dibandingkan dengan Shannon Entropy-ARAS dengan hasil $74,75263 \%$. Hal ini dikarenakan pada penentuan bobot awal metode $S W A R A$ berdasarkan si pengambil keputusan atau $H R$ dalam bentuk persentase yang memiliki perbedaan dengan Shannon Entropy yang penentuan bobot awalnya berdasarkan alternatif data penyeleksian calon karyawan. Oleh karena itu, dapat disimpulkan bahwa metode SWARA-ARAS merupakan metode paling sesuai atau sensitif dengan kasus penyeleksian calon karyawan pada penelitian ini. Dari hasil tersebut, metode SWARA-ARAS direkomendasikan untuk penyelesaian penyeleksian calon karyawan.

\section{KESIMPULAN}

Hasil penelitian uji sensitivitas dengan melakukan perubahan bobot sebesar 0,3 pada metode SWARAARAS mendapatkan hasil 91,24203 \% lebih tinggi dibandingkan metode Shannon Entropy-ARAS dengan hasil 74,75263\%. Penelitian ini dapat dikembangkan dengan melakukan metode pembobotan antar kriteria lainnya seperti metode $A H P$, sehingga diharapkan hasil alternatif lebih baik dibandingkan dengan metode SWARA.

\section{DAFTAR PUSTAKA}

[1] N. Hermaduanti and S. Kusumadewi, "Sistem Pendukung Keputusan Berbasis Sms Untuk Menentukan Status Gizi Dengan Metode KNearest Neighbor,” Semin. Nas. Apl. Teknol. Inf. ISSN 1907-5022, no. Juni, pp. 49-56, 2008.

[2] E. Turban, J. Aronson, and T. Llang, Decision Support Systems and Intelligent Systems. Yogyakarta: Andi, 2005.

[3] C. H. Yeh, "A Problem-based Selection of Multi-attribute Decision-making Methods," Int. Trans. Oper. Res., vol. 9, no. 2, pp. 169-181, 2002, doi: 10.1111/1475-3995.00348.

[4] E. Triantaphyllou, “A Sensitivity Analysis Approach for MCDM Methods,” pp. 131-175, 2000, doi: 10.1007/978-1-4757-3157-6_8.

[5] E. K. Zavadskas and Z. Turskis, "A new additive ratio assessment (ARAS) method in multicriteria decision-making," Technol. Econ. Dev. Econ., vol. 16, no. 2, pp. 159-172, 2010, doi: 10.3846/tede.2010.10.

[6] D. S. W. Lubis and E. Murlisah, "Sistem Pendukung Keputusan Pemilihan Guru Terbaik Menggunakan Metode Additive Ratio Assessment ( ARAS )," Sainteks, no. Januari, pp. 448-455, 2019.

[7] R. Fachrizal, "Implementasi ARAS ( Additive Ratio Assessment ) Dalam Pemilihan Kasir Terbaik Studi Kasus Outlet Cardinal Store Plaza Medan Fair," Sainteks, no. Januari, pp. 501-510, 2019.

[8] A. Aytekin et al., "Analyzing Financial Performance of Insurance Companies Traded In BIST via Fuzzy Shannon's Entropy Based Fuzzy TOPSIS Methodology," J. Oper. Res. Stat. Alphanumeric J. Alphanumeric J., vol. 5, no. 1, pp. 71-84, 2017, doi: 10.17093/alphanumeric.323832.

[9] F. H. Lotfi and R. Fallahnejad, "Imprecise shannon's entropy and multi attribute decision making," Entropy, vol. 12, pp. 53-62, 2010, doi: 10.3390/e12010053.

[10] R. K. Mavi, M. Goh, and N. K. Mavi, "Supplier Selection with Shannon Entropy and Fuzzy TOPSIS in the Context of Supply Chain Risk Management," Procedia - Soc. Behav. Sci., vol. 235, no. October, pp. 216-225, 2016, doi: 10.1016/j.sbspro.2016.11.017.

[11] E. Ebrahimi, M. R. Fathi, and H. R. Irani, "A new hybrid method based on fuzzy Shannon's Entropy and fuzzy COPRAS for CRM performance evaluation (Case: Mellat Bank)," Iran. J. Manag. Stud., vol. 9, no. 2, pp. 333-358, 2016, doi: 10.22059/ijms.2016.56414.

[12] S. Hashemkhani Zolfani, M. Yazdani, and E. K. Zavadskas, "An extended stepwise weight assessment ratio analysis (SWARA) method for improving criteria prioritization process,” Soft Comput., vol. 22, no. 22, pp. 7399-7405, 2018, doi: 10.1007/s00500-018-3092-2.

[13] D. Stanujkic, D. Karabasevic, and E. K. Zavadskas, "A framework for the selection of a packaging design based on the SWARA method," Eng. Econ., vol. 26, no. 2, pp. 181-187, 2015, doi: 10.5755/j01.ee.26.2.8820.

[14] S. Hashemkhani Zolfani and M. Bahrami, "Investment prioritizing in high tech industries based on SWARA-COPRAS approach," Technol. Econ. Dev. Econ., vol. 20, no. 3, pp. 534-553, 2014, doi: 10.3846/20294913.2014.881435. 


\section{Jurnal ELTIKOM :}

Jurnal Teknik Elektro, Teknologi Informasi dan Komputer

[15] D. Karabasevic, D. Stanujkic, and S. Urosevic, "The MCDM Model for Personnel Selection Based on SWARA and ARAS Methods," Manag. - J. theory Pract. Manag., pp. 43-52, 2015, doi: 10.7595/management.fon.2015.0029.

[16] V. Keršuliene, E. K. Zavadskas, and Z. Turskis, "Racionalaus ginčụ sprendimo būdo nustatymas taikant naujạ kriterijụ svoriụ nustatymo metodą, pagrịstạ nuosekliu laipsnišku poriniu kriterijụ santykinès svarbos lyginimu," J. Bus. Econ. Manag., vol. 11, no. 2, pp. 243-258, 2010, doi: 10.3846/jbem.2010.12. 